\title{
INKORPORACJA PARAFII ZDEZORGANIZOWANEJ W RZECZYPOSPOLITEJ W OKRESIE POTRYDENCKIM NA PRZYKLADZIE PARAFII SLUPIE I MODLIBORZYCE W DIECEZJI KRAKOWSKIEJ
}

Studium przypadku parafii Słupie i Modliborzyce pozwala szczegółowo przeanalizować proces zarówno terytorialnej, jak i administracyjno (funkcjonalno)-materialnej inkorporacji parafii w Rzeczypospolitej w okresie potrydenckim. Naświetla przyczyny tego procesu, daje wgląd w jego przebieg, wreszcie pozwala przeanalizować przeszkody, które wpływały na tempo inkorporacji. Dzięki niemu ocenić możemy sposób w jaki likwidowano odrębność przeznaczonego do inkorporacji okręgu parafialnego, ale także opisać funkcjonowanie parafii w swoistym międzyczasie, tj. między dokonaną już inkorporacją terytorialną, a trwającą jeszcze i rozłożoną w czasie inkorporacją materialną, gdy nowa parafia cechowała się pewnym dualizmem funkcjonowania. Jednolita pod względem terytorialnym parafia inkorporująca funkcjonowała wówczas bowiem jeszcze $\mathrm{z}$ aktywnym wykorzystaniem zabudowań nieistniejącej już formalnie parafii inkorporowanej. Inkorporacja parafii jawi się nam tym samym jako proces rozłożony w czasie i wieloetapowy.

Pod terminem incorporatio rozumiano wcielenie, właczenie czegoś w jakaś całość, zjednoczenie, przyłączenie ${ }^{l}$. W XVII w. terminem inkorporacji posługiwały się dość często konstytucje sejmowe na określenie „włączenia” jakiegoś gruntu do dóbr kościelnych ${ }^{2}$. W odniesieniu do rozwoju sieci parafialnej zjawiskiem sta-

* Dominik Szulc - dr historii, adiunkt w Instytucie Historii im. Tadeusza Manteuffla PAN wWarszawie, e-mail: dszulc@ihpan.edu.pl

${ }^{1}$ Elektroniczny Stownik Łaciny Średniowiecznej, http://scriptores.pl/elexicon/dostep/singleView.html?what=incorporatio\#haslo_pelny (dostęp: 14.08.2016).

${ }^{2}$ Patrz m.in. konstytucje sejmu warszawskiego 1673 r. w: Volumina legum, t. 5, wyd. J. Ohryzki, Petersburg 1860, s. 68-69, fol. 110 (Inkorporacya wsi Rayska do kościoła Panny Maryi Borkowskiey), fol. 111 (Inkorporacya dwoch włok do kościoła Swiezkiego), fol. 111 (Inkorporacya drogi OO: Bernardynom w Łucku). 
nowiącym przeciwieństwo inkorporacji była parcelacja parafii ${ }^{3}$. Obecnie terminem inkorporacji powszechnie posługują się historycy państwa i prawa, rozumiejąc go najczęściej jako włączenie danego terytorium, lub jego części do terytorium sąsiedniego, likwidujące problemy graniczne między nimi ${ }^{4}$. Już w latach międzywojennych podnoszono, że o inkorporacji można mówić tylko w odniesieniu do dwóch „nierównych” sobie organizmów prawnych ${ }^{5}$, przy czym rozróżniano inkorporację bezpośrednią i pośrednią ${ }^{6}$. Stanisław Kutrzeba podczas dyskusji na VI Zjeździe Historyków Polskich w Wilnie w 1935 r. zaproponował zbadanie i podjęcie próby przeniesienia na grunt polityczny dawnych relacji polsko-litewskich, rozumienia terminu inkorporacji przez ówczesne prawo kościelne. Zaznaczył, że sam nie mógł zagadnieniu temu „poświęcić dość czasu”. Moim zdaniem pamiętać należy jednak o swoistości polskiej sieci parafialnej ${ }^{7}$ i oczekiwanej trudności w przeniesieniu na grunt relacji państwowo-prawnych schematu procesu inkorporacji parafii ${ }^{8}$. Niemniej dostrzegam pewne wspólne cechy inkorporacji parafii i inkorporacji organizmów politycznych. Już synod prowincjonalny piotrkowski z 1564 r. nakazywał inkorporowanie do sąsiednich, dobrze zorganizowanych parafii, tych zdezorganizowanych ${ }^{9}$. Było to prawdopodobnie konsekwencją obrad Soboru Trydenckiego. Podczas XXI Sesji soborowej 16 lipca 1562 r. przyjęto bowiem „Dekret o reformie”, którego kanon 5 nakazywał łączyć z sobą ubogie parafie $^{10}$. Brzmiał on:

Ponadto, aby kościoły (...) utrzymać na poziomie odpowiednim do ich godności, biskupi (...) mogą ustanawiać wieczyste połączenia jakichkolwiek kościołów parafialnych i tych, gdzie udzielany jest sakrament chrztu, oraz innych

${ }^{3}$ A. Rozwałka, Sieć osadnicza $w$ archidiakonacie lubelskim $w$ średniowieczu. Studium archeologiczno-historyczne, Lublin 1999, s. 53-54; por. S. Jop, Zasiedlenie Pojezierza w rejonie Ostrowa Lubelskiego (XIII-XVIII w.), Lublin 1998, s. 89.

${ }^{4}$ Zob. m.in. J. Adamus, O prawno państwowym stosunku Litwy do Polski. Dyskusja, w: Pamiętnik VI Powszechnego Zjazdu Historyków Polskich w Wilnie 17-20 września 1935 r., cz. 2 (ProtokoŁy), Lwów 1936, s. 86-87.

${ }^{5}$ Tamże, s. 86.

${ }^{6}$ L. Sobolewski, Prawne aspekty unii polsko-litewskiej na przełomie XV i XVI wieku, Kraków 1994 (mps rozprawy doktorskiej w Archiwum Akt Nowych Biblioteki Jagiellońskiej), s. 112.

${ }^{7}$ Wyrażała się ona chociażby z nie nakładaniu się np. okręgów parafialnych na tzw. okręgi dziesięcinne (por. P. Plisiecki, Z badań nad siecia parafialna i dziesięcinna. Przyktad parafii w Dobrowodzie, „Teka Komisji Historycznej. Oddział PAN w Lublinie”, 1 (2004) s. 5 i nn.). Przekazywanie części dziesięciny plebanowi w Potoku przez plebana w ówczesnej Słupi Dłotowej w archidiakonacie zawichojskim w 1529 r. i wcześniej, nie świadczy o planach włączenia parafii słupskiej do potockiej, a jest raczej reliktem dawnej przynależności parafialnej terenów ówczesnej parafii w Słupi. Podobnie dość powszechne w XVI w. zjawisko kumulacji beneficjów plebańskich nie świadczyło jeszcze o zamiarze przeprowadzenia inkorporacji parafii (S. Litak, Parafie w Rzeczypospolitej w XVI-XVIII wieku. Struktura, funkcje społeczno-religijne i edukacyjne, Lublin 2004, s. 148-154).

${ }^{8}$ Por. E. Wiśniowski, Parafie w średniowiecznej Polsce, Lublin 2004, s. 54-55, 59, 67.

${ }^{9}$ J. Sawicki, Consilia Poloniae. Źródta i studia krytyczne, t. 7, Synody diecezji poznańskiej i ich statuty, Poznań 1952, s. 70.

${ }^{10}$ B. Kumor, Dzieje diecezji krakowskiej, t. 4, Kraków 2002, s. 236. 
beneficjów, związanych z pracą duszpasterską, a także z nią niezwiązanych, $\mathrm{z}$ kościołami związanymi z pracą duszpasterską, z powodu ubóstwa tych kościołów, a także w innych przypadkach dopuszczonych w prawie, nawet gdyby wspomniane kościoły albo beneficja były zastrzeżone ogólnie bądź szczegółowo czy też w jakikolwiek sposób przyznane. Połączenia te nie mogą być również odwołane ani w żaden sposób umniejszone $(. . .)^{11}$.

Z kolei kanon 7 zezwalał biskupom ,,przenosić“ beneficia z kościołów zrujnowanych do tych lepiej zorganizowanych znajdujacych się w pobliżu, o ile brak było perspektyw na podniesienie z ruiny tego pierwszego:

Dlatego biskupi (...) mogą wedle swego osądu przenosić proste beneficja, nawet objęte prawem patronatu, z kościołów, które z powodu wieku albo z innej przyczyny popadły w ruinę, a które z powodu ubóstwa nie mogą być odnowione, po wezwaniu osób, których to dotyczy, do kościołów macierzystych albo do innych kościołów na tym terenie bądź w pobliżu (...). Biskupi zatroszczą się także o odnowienie i przywrócenie do dawnego stanu zrujnowanych kościolów parafialnych, nawet gdyby pozostawały pod prawem patronatu, z dowolnych zysków i dochodów, które w jakikolwiek sposób przynależą do tych kościołów. Gdyby zaś te dochody nie były wystarczające, wtedy biskupi skłonią, za pomocą wszelkich stosownych środków, wszystkich patronów i inne osoby, które otrzymują jakiekolwiek zyski ze wspomnianych kościołów, albo w razie ich braku, wszystkich parafian, do pokrycia powyższych kosztów odnowy, bez względu na jakiekolwiek odwołania, wyłączenia i sprzeciwy. Natomiast gdyby wszyscy byli zbyt ubodzy, wtedy te kościoły zostaną przeniesione do kościołów macierzystych albo sąsiednich ${ }^{12}$.

Przepisy te zostały inkorporowane do polskiego systemu prawnego przez Zygmunta Augusta podczas sejmu parczewskiego w sierpniu 1564 r. ${ }^{13}$ Czynnikiem, który warunkował konieczność inkorporacji parafii był zły stan wielu okręgów powstały m.in. wskutek rozpowszechniania sie nurtów reformacji nie tylko wśród patronów, ale również samych duchownych, którzy zaczęli opuszczać powierzone im beneficja. Ks. Bolesław Kumor zauważył, że ok. 1565 r. aż 17 parafii archidiakonatu lubelskiego zostało opuszczonych przez swoich proboszczów na skutek zajęcia przynależnych im dochodów dziesięcinnych przez patronów kościołów ${ }^{14}$.

\section{Lokacja miasta i fundacja kościoła w Modliborzycach jako czynniki ini- cjujące proces inkorporacji}

Wieś Słupie leżała w dekanacie urzędowskim archidiakonatu zawichojskiego diecezji krakowskiej, a tamtejsza parafia erygowana została zapewne niedługo przed listopadem 1412 r. na prośbę miejscowego właściciela ziemskiego i fundatora kościoła słupskiego, rycerza Jana Dłoty. Choć już z końcem XVI w. datuje się pierwsze poświadczone źródłowo oznaki „dezorganizacji” tej parafii, to

${ }^{11}$ Dokumenty Soborów Powszechnych, t. 4 (1511-1870), opr. A. Baron, H. Pietras, Kraków 2005, s. 618-619.

12 Tamże, s. 622-623.

${ }^{13} \mathrm{~W}$. Malesa, Synody piotrkowskie a polskie zwyczaje liturgiczne zachowane po przyjęciu trydenckiej reformy liturgii, „Kultura-media-teologia”, 17 (2014) s. 97.

${ }^{14}$ Kumor, Dzieje diecezji krakowskiej, s. 603. 
jednak moim zdaniem nie one, lecz inne czynniki zainicjowały proces późniejszej inkorporacji parafii słupskiej do modliborzyckiej. Były nimi lokacja w pobliżu Słupiów miasta Modliborzyce, a następnie ufundowanie tam kościoła, który w przyszłości stał się ośrodkiem nowej parafii, do której z czasem inkorporowano parafię słupską. W inicjatorze tego procesu, który przyczynił się do niego swoją działalnością fundacyjną i gospodarczą, dostrzegam założyciela Modliborzyc i fundatora tamtejszego kościoła Stanisława Wieteskiego herbu Rola, który jednocześnie był właścicielem Słupiów. Ks. B. Kumor wśród przyczyn znoszenia samodzielności parafii w tym czasie wymienił bowiem „dążność wielkiej własności [...] szlacheckiej do centralizacji zarządu gospodarczego" "15. Akcja przeniesienia siedziby parafii ze Słupi do Modliborzyc lub inkorporacji parafii słupskiej do modliborzyckiej, byłaby zatem ułatwiona dzięki temu, iż Wieteski był właścicielem obu miejscowości. Stan taki utrzymywał się także w pierwszych kilkunastu latach po jego śmierci.

Stanisław Wieteski był synem Jana ${ }^{16}$, prawdopodobnie oficjalisty ${ }^{17} \mathrm{u} \mathrm{Za}$ moyskich ${ }^{18}$. Bratem Stanisława był przypuszczalnie Jakub Wieteski, który wraz z żoną oraz córkami trzymał w latach 1632-1634 połowę nieodległego względem Słupiów, Potoku Stany ${ }^{19}$ należącego do parafii potockiej. Późniejszy fundator kościoła w Modliborzycach, sam był pierwotnie oficjalistą, a następnie podskarbim Zamoyskich. Dnia 7 listopada 1626 r. został nominowany na urząd stolnika w ziemi bełskiej ${ }^{20}$. Zdaniem Henryka Gmiterka zginął podczas powstań kozackich niedługo po 1650 r. ${ }^{21}$ Dziedzicem Bychawy w 1654 r. był już jego syn Jan ${ }^{22}$. Stanisław miał zostać pochowany wraz z rodziną w kryptach kościoła modliborzyckiego ${ }^{23}$.

W pierwszej ćwierci XVII w. w Słupiach i w ich pobliżu wśród właścicieli ziemskich pojawiła się nowa średnia szlachta folwarczna (nie zarejestrowano własności duchownej) - Rzeczyccy i Chobrzyńscy ${ }^{24}$. Niewykluczone, że to od

15 Tamże, s. 375.

${ }^{16}$ Archiwum Państwowe w Kielcach, Oddział w Sandomierzu (dalej: APK, O.S.), Hipoteka janowska, sygn. 949/189, nr 4 (wypis z księgi grodzkiej lubelskiej z 1802 r.), bp.

${ }^{17}$ Osoba zatrudniona w administracji Ordynacji Zamoyskiej jako np. administrator, nadleśniczy czy ekonom.

${ }^{18}$ Por. Archiwum Główne Akt Dawnych w Warszawie, Archiwum Zamoyskich (dalej: AGAD, AZ), sygn. 749, s. 43-45.

${ }^{19}$ Zob. Archiwum Państwowe w Lublinie, Księgi ziemskie urzędowskie (dalej: APL, KzU), ks. 22, k. 85v-86v, 140-140v, 244-244v, 362-364v.

${ }^{20}$ Urzędnicy województwa betskiego i ziemi chetmskiej XIV-XVIII wieku. Spisy, opr. H. Gmiterek, R. Szczygieł, Kórnik 1992, s. 66.

${ }^{21}$ H. Gmiterek, Dzieje miasta $w$ XVII-XVIII wieku, w: Dzieje Bychawy, red. R. Szczygieł, Bychawa-Lublin 1994, s. 57.

${ }^{22}$ Zob. Materiały źródłowe do dziejów Żydów w księgach grodzkich lubelskich z doby panowania Władysława IV i Jana Kazimierza Wazów 1632-1669, Judaica Lublinensia, t. 3, opr. H. Gmiterek, Lublin 2006, s. 120, nr 689.

${ }^{23}$ Por. B. Chlebowski, R. Przegaliński, Modliborzyce, w: Słownik geograficzny Królestwa Polskiego i innych krajów słowiańskich, t. 6, Warszawa 1885, s. 566.

${ }^{24}$ Zakład Narodowy im. Ossolińskich we Wrocławiu (dalej: B. Ossol.), sygn. 86/II, k. 74. 
nich Słupie zakupił S. Wieteski. W 1631 r. był już bowiem właścicielem nie tylko wsi Słupie, ale także należących do jej parafii Wierzchowisk ${ }^{25}$, o dziesięciny z których toczył wówczas spór z plebanem słupskim ks. Stanisławem Ligockim ${ }^{26}$. Jednocześnie uzyskał od króla Zygmunta III Wazy zgodę na lokację przestrzenną miasta Modliborzyce na gruntach Słupiów ${ }^{27}$. Lokacja i rozwój przestrzenny tego miasta musiały spełniać rolę czynników sprawczych fundacji kościoła ${ }^{28}$. Potwierdza to przywilej lokacyjny Modliborzyc z 1642 r., w którym Wieteski darował nowemu kościołowi:

Grunt osobny [...] w Miasteczku należący, poczyna się od koła wału wedle samych Rynkowych zatyłków zachodnich, aż po gościnieć który z miasta bierzy ku potokach [ku Potokowi - D.Sz., S.T.] za którym gościńcem także temuż Kościołowi będzie wszytek grunt Tworkowski [Tworka? - D.Sz., S.T.] wedle zatyłków ulicy drugiej od wału aż po sam płot Topornickiego po sadek należał ${ }^{29}$.

Być może był to też element pewnego większego planu Wieteskiego, jaki realizował przejmując na własność nowe majątki. Zdaniem Teresy Teodorowicz-Czerepińskiej Wieteski ufundował bowiem przed 1639 r. w Bychawie murowany kościół ${ }^{30}$, co mogło pozostawać w związku z przejęciem przez niego miasta na własność dziedziczną, co nastąpiło zapewne w latach 1636-163731. W planach Wieteskiego mogło być jeszcze wybudowanie przy kościele modliborzyckim klasztoru dla kanoników regularnych lateraneńskich, nie jest to jednak pewne ${ }^{32}$.

${ }^{25}$ APL, KzU, sygn. 22, k. 168v-170.

${ }^{26}$ Tamże, k. $168 \mathrm{v}-170$.

${ }^{27}$ Tamże, k. 145v; J. Łosowski, Kancelarie miast szlacheckich województwa lubelskiego od XV do XVIII wieku, Lublin 1997, s. 100.

${ }^{28}$ Por. P. Szafran, Rozwój średniowiecznej sieci parafialnej w Lubelskiem, Lublin 1958, s. $97-$ 98.

${ }^{29}$ Przywilej miasta Modliborzyc, wyd. U. Bzdyra, „Wieści Gminne. Wydanie specjalne - 380 lat lokacji Modliborzyc", 9 (2011) s. 5.

${ }^{30} \mathrm{~T}$. Teodorowicz-Czerepińska, Rejestr wartości kulturowych województwa lubelskiego, Lublin 1990, s. 11.

${ }^{31}$ Zob. Gmiterek, Dzieje miasta, s. 56-57. Podobne sytuacje zdarzały się także później w innych dobrach prywatnych. Lokacja miasta Annopola w parafii Świeciechów w archidiakonacie zawichojskim w 1740 r. zbiegła się w czasie z fundacją tamże już rok później filii kościoła świeciechowskiego. W Świeciechowie jednak, w przeciwieństwie do Słupiów i Modliborzyc, ośrodek parafialny utrzymał się po dziś dzień, zaś kościół w Annopolu usamodzielnił się dopiero w końcu XIX w. (por. W. Szymanek, Z dziejów powiatu janowskiego i kraśnickiego w latach 1474-1975, Kraśnik 2003, s. 267).

${ }^{32}$ Mieli oni opiekować się nowo wzniesionym kościołem, o czym jako pierwsi napisali dopiero B. Chlebowski i R. Przegaliński w końcu XIX w. na łamach Słownika Geograficznego. Jak dotychczas nie udało się potwierdzić wiarygodności tej informacji, jakkolwiek w latach po ok. 1630 r. nastąpił znaczny wzrost zainteresowania konwentem kanoników w nieodległym Kraśniku. W wyniku przeprowadzonej tam do 1644 r. reformy wewnętrznej, kraśnicki klasztor nie tylko przejął miejscową prepozyturę szpitalną (1633), wzbogacił się o nowe, barokowe wyposażenie, poprawiła się dyscyplina życia wewnętrznego zakonników, ale także uzyskał znaczne darowizny, zwłaszcza ze strony mieszczan oraz średnio zamożnej szlachty powiatu urzędowskiego (m.in. Rzeczyccy, Wy- 
Niewiele mamy materialnych śladów świadczących o czasie budowy kościoła w Modliborzycach. Pierwotny kościół pw. św. Stanisława Biskupa nie będący jeszcze parafialnym i wzniesiony zapewne $\mathrm{z}$ drewna ${ }^{33}$, miano ufundować rzekomo już w 1629 r., a więc dwa lata przed wydaniem przez Zygmunta III pierwszego przywileju lokacyjnego dla Modliborzyc ${ }^{34}$. Dyplom fundacyjny tego kościoła przechowywano bowiem, zdaniem wizytatora ks. Antoniego Franciszka DuninKozickiego, w bibliotece parafialnej w Modliborzycach jeszcze w $1781 \mathrm{r}^{35}$, zaś jego wystawcą miał być Stanisław Wieteski ${ }^{36}$. Wydaje się to jednak wątpliwe. $\mathrm{O}$ dokumencie tym oraz istnieniu kościoła w Modliborzycach od 1629 r. nie wspominają zachowane jego XVII-wieczne wizytacje. Możliwe jest zatem, że do tekstu wizytacji z $1781 \mathrm{r}$. wkradł się błąd, tym bardziej, że w $1629 \mathrm{r}$. Modliborzyce jeszcze nie istniały. Dopiero bowiem w przywileju Zygmunta III z 1631 r. czytamy o dokonanej przez króla zamianie wsi dziedzicznej Słupie na miasto Modliborzyce $^{37}$. Z kolei ks. Leon Kuśmierczyk, Grzegorz Kotuła i Urszula Bzdyra wyrazili opinię, że kościół modliborzycki wzniesiono w 1634 r., choć ze względu na wskazaną przez nich rzekomą lokalizację pierwotnej świątyni przy późniejszym rynku Modliborzyc także te tezy wydają się wątpliwe ${ }^{38}$. Z kolei ks. Jan Ambroży Wadowski ${ }^{39}$ oraz ks. Józef Bazylak przekonani byli, iż kościół wzniesiono dopiero w $1664 \mathrm{r}^{40}$, choć w przywołanej przez tego drugiego wizytacji z $1682 \mathrm{r}$. brak takiej informacji ${ }^{41}$. Według ks. Karola Broniewskiego data, „1 czerwca 1643” wyryta na odrzwiach kościoła modliborzyckiego nie może być przypadkowa i w związku z przywilejem lokacyjnym miasta wystawionym przez Wieteskiego w $1642 \mathrm{r}$.

branowscy, Olbięccy) wśród której znalazł się również „sąsiad” Wieteskiego, właściciel Potoku Andrzej Drwalewski (por. L. Makuch, Uposażenie kanoników regularnych w Kraśniku, „Regionalista”, 2 (1994) s. 39; E. Zielińska, Kultura intelektualna kanoników regularnych z klasztoru w Kraśniku w latach 1469-1563, Lublin 2002, s. 59-60; I. Rolska, Od gotyku do baroku. Kościót Kanoników Regularnych w Kraśniku w okresie patronatu Tęczyńskich i Zamoyskich, w: Ars omnia vincit. Studia $z$ dziejów sztuki i kultury artystycznej, red. A. Bender, M. Kierczuk-Macieszko, Lublin 2012, s. 344). Powtórzenie w Modliborzycach darowizn znanych z Kraśnika wpłynęłoby z pewnością pozytywnie na stan finansów Wieteskiego, które musiały być uszczuplone po tak poważnej inwestycji jaką było wzniesienie murowanego kościoła trójnawowego.

${ }^{33}$ Por. Biblioteka Polskiej Akademii Nauk i Polskiej Akademii Umiejętności w Krakowie (dalej: BPAN-PAUKr.), sygn. 2375 (J.A. Wadowski, Kościoły w Lublinie i diecezji krakowskiej, t. 1), s. 329.

${ }^{34}$ Łosowski, Kancelarie miast szlacheckich województwa lubelskiego, s. 100.

${ }^{35}$ Archiwum Archidiecezjalne Lubelskie (dalej: AAL), Rep. 60, sygn. A 105, s. 564.

${ }^{36}$ Zob. Gmiterek, Dzieje miasta, s. 56-57.

${ }^{37}$ Por. AGAD, Komisja Rządowa Spraw Wewnętrznych i Policji, sygn. 3194, s. 193.

${ }^{38}$ L. Kuśmierczyk, Rozwój zaludnienia parafii Stupie-Modliborzyce, „Korzenie Janowskie”, 10 (2008), s. 24; G. Kotuła, [mps pracy magisterskiej poświęconej dziejom parafii modliborzyckiej], Lublin 2005, s. 34; U. Bzdyra, Dzieje Modliborzyc. Kalendarium, „Wieści Gminne”, nr 10 (2008), s. 23. Ks. Kuśmierczyk uważał, że był to kościół „tymczasowy”.

${ }^{39}$ BPAU-PANKr., sygn. 2375, s. 330.

${ }^{40}$ J. Bazylak, Zarys historii parafii Modliborzyce (cz. 1), „Korzenie Janowskie”, nr 6 (2006), s. 18 .

${ }^{41}$ Archiwum Kurii Metropolitalnej Krakowskiej (dalej: AKMKr.), AV, sygn. 12, s. 120. 
musi oznaczać początek budowy murowanej świątyni ${ }^{42}$. Pogląd ten także wydaje się błędny, gdyż odrzwia te przeniesiono do Modliborzyc z pozostałości kościoła słupskiego dopiero niedługo przed $1885 \mathrm{r}$., tj. ok. 15-20 lat przed powstaniem tekstu Broniewskiego ${ }^{43}$. Tymczasem znajdująca się obecnie w kościele modliborzyckim barokowa tablica kamienna z ok. połowy XVIII w. informuje o wzniesieniu świątyni przez Wieteskiego w $1661 \mathrm{r} .{ }^{44} \mathrm{~W}$ prezbiterium świątyni znajduje się ponadto późnorenesansowa dekoracja stiukowa w tzw. typie lubelsko-kaliskim datowana dotychczas na lata ok. 1664-1668 r. Zawiera ona przedstawienia m.in. herbu Rola Wieteskich i monogram fundatora $-\boldsymbol{S} \boldsymbol{Z} \boldsymbol{M} \boldsymbol{W} \boldsymbol{S} \boldsymbol{B}$ (Stanisław $\mathbf{z}$ Modliborzyc Wieteski stolnik bełski) ${ }^{45}$. Biorąc jednak pod uwagę zaniechanie przez Wieteskiego działalności publicznej i domniemaną śmierć po 1650 r. oraz małe prawdopodobieństwo umieszczenia na dekoracji stiukowej w kościele monogramu fundatora już po jego śmierci, należałoby przyjąć, że dekoracja ta pochodzi raczej sprzed tego czasu. Niedawno Roman Zwierzchowski wyraził pogląd, że kościół modliborzycki zaczęto wznosić ,,ponoć” od 1645 r., co ze względu na późniejsze wojny Rzeczypospolitej, miało trwać aż do połowy XVII w. ${ }^{46}$ Co ciekawe o ile w dokumencie lokacyjnym Modliborzyc z 1642 r. nie wspomniano o czasie w jakim miano wznieść nowy kościół, o tyle w dokumencie lokacyjnym Tomaszowa (ob. Lubelskiego) z 1621 r. ${ }^{47}$, który zdaniem Ryszarda Szczygła stanowił dla Wieteskiego „wzór” przy wystawianiu analogicznego dokumentu dla Modliborzyc, mowa jest o konieczności wybudowania kościoła w ciągu trzech lat ${ }^{48}$. Gdyby w przypadku Modliborzyc miało być podobnie tamtejsza świątynia musiałaby zostać wzniesiona do $1645 \mathrm{r}^{49}$ Tym samym wykonano by pierwszy krok zmierzający do ustanowienia w Modliborzycach nowego ośrodka parafii, której centrum wciąż jeszcze były Słupie.

${ }^{42}$ K. Broniewski, Modliborzyce, w: Monografia ilustrowana kościołów rzymskokatolickich w Królestwie Polskim, z. 1, Warszawa 1899, s. 96.

${ }^{43}$ Chlebowski, Przegaliński, Modliborzyce, s. 565.

${ }^{44}$ Katalog zabytków sztuki w Polsce, t. 8, red. R. Brykowski, Z. Winiarz, z. 7, przyg. I. Galicka, E. Rowińska, Warszawa 1961, s. 11.

${ }^{45}$ Por. tamże.

${ }^{46}$ R. Zwierzchowski, Modliborzyce. Korekta zasięgu wpisu do rejestru zabytków układu urbanistycznego - nr rej. zabytków woj. lubelskiego. A/566, Lublin 2008, mps w Archiwum Wojewódzkiego Urzędu Ochrony Zabytków w Lublinie, s. 4.

${ }^{47}$ Zob. Przywilej lokacyjny miasta Tomaszowa z 1621 roku, do druku przyg. R. Szczygieł, Tomaszów Lubelski 2012, s. 10-17.

${ }^{48}$ R. Szczygieł, Dokument lokacyjny miasta Tomaszowa wzorem przy spisaniu dokumentu lokacyjnego Modliborzyc z 1642 r., w: Między tekstem a znakiem. Prace ofiarowane Profesor Barbarze Trelińskiej w siedemdziesiata rocznicę urodzin, red. A. Jaworska, S. Górzyński, Warszawa 2013, s. 396. Jego zdaniem był on jedynym obok ratusza budynkiem, którego nie wzniesiono do chwili ogłoszenia dokumentu lokacyjnego (zob. tenże, Powstanie miasta Jelitowa (Tomaszowa) i jego dzieje w czasach rządów w Ordynacji kanclerskiej linii Zamoyskich, w: Tomaszów Lubelski. Monografia miasta, red. R. Szczygieł, Lublin-Tomaszów Lubelski 2011, s. 99).

${ }^{49}$ Co ciekawe to właśnie od 1645 r., nie zaś już od 1642, władze miejskie miały pobierać ogół targowego, a więc opłaty wnoszonej przez mieszczan za wystawienie swojego towaru przez domami i w rynku (Przywilej miasta Modliborzyc, s. 5). 


\section{Dezorganizacja ośrodka parafialnego w Słupiach jako czynnik sprzyja- jący inkorporacji}

Wydaje się, że lokacja Modliborzyc była czynnikiem sprawczym nie tylko fundacji tamtejszego kościoła, ale także bezpośrednio przyczyniła się do pogłębienia stanu dezorganizacji parafii słupskiej. Stan ten pierwszy raz odnotowano już w 1592 r., a zatem na długo przed powstaniem Modliborzyc. Stan należących do parafii zabudowań kościelnych daleki był wówczas od zadowalającego. Zarówno dach kościoła, jak i dzwonnicy oraz kostnicy przeciekały. W złym stanie były cyborium oraz chrzcielnica. Egzaminowany przez wizytatora biskupiego ks. Andrzeja z Żarnowca z mszy świętej pleban słupski ks. Piotr Dąbrowski odpowiadał „chłodno”. Wizytator zwrócił uwagę na szereg niepokojących zachowań plebana. Nie upominał się mianowicie o zwrot kilku łanów z uposażenia ziemskiego, jakie mieli mu odebrać sukcesorzy fundatora kościoła w Słupiach. Lubił pić wino i piwo, które spożywał zarówno na plebanii, jak i w karczmie. Towarzyszył mu przy tym szwagier, mieszkający wraz z jego siostrą przy kościele. Miejscowi posesorzy czynili przy tym zabiegi, aby uniknąć odprowadzania dziesięciny należnej plebanowi słupskiemu ${ }^{50}$. W 1598 r. stan całości zabudowań kościelnych chyba wciąż nie był należyty, skoro kościół był źle pomalowany (non bene tecta), baptysterium nie było wykończone (non clausu), zaś dom plebana użytkowany był od dawna (vetustate consumpta). Ponadto w kościele wciąż brak było ksiąg ${ }^{51}$ (agenda non sunt), natomiast nieobecność rektora kościoła ks. Dąbrowskiego uniemożliwiła przeprowadzenie szczegółowej wizytacji. Pleban nie przeprowadził ponadto kolędy po świętach Bożego Narodzenia $1597 \mathrm{r}$. Mimo tego wizytator nie wyznaczył mu wikarego. Parafię musiała także dotknąć propaganda reformacji, skoro wizytator odnotował pogrzebanie na cmentarzu przykościelnym niejakiej Stojeńskiej - „heretyczki” (haeritica) ${ }^{52}$ oraz dwóch jej synów. Niewykluczone, że chodziło tu o żonę miejscowego luteranina Jana Stojeńskiego. Nieprzypadkowa może być zatem zbieżność pojawienia się nazwy miejscowej Lute (Luthe) w 1626 $\mathrm{r}^{53}$ oraz dezorganizacji parafii słupskiej, w okresie gdy właścicielem należącej do niej wsi Woli był Stojeński ${ }^{54}$. Nie wykluczam, że to w tym okresie doszło do założenia nowej osady o nazwie Lute, bądź zmiany nazwy części wsi Słupie lub Woli-Wolicy na Lute. Nowa nazwa miejscowa ukształtowana zostałaby od łacińskiego terminu określającego niektórych innowierców, wspomnianych właścicieli Woli - lutherani ${ }^{55}$. Stąd być może pochodzi najstarszy zapis nazwy wsi w zlatynizowa-

${ }^{50}$ AKMKr., AV, sygn. 1, s. 21-22.

${ }^{51}$ Zapewne liturgicznych i metrykalnych.

${ }^{52}$ Archiwum Kapituły Katedralnej Krakowskiej, depozyty, sygn. 12, b.p.

${ }^{53}$ Ks. L. Kuśmierczyk mylnie uważał, że wieś ta pierwszy raz wzmiankowana została w 1529 r., a powstała rzekomo niedługo wcześniej (Kuśmierczyk, Rozwój zaludnienia parafii Stupie-Modliborzyce, s. 24).

${ }^{54}$ AKMKr., AV, sygn. 1, s. 21; J. Bazylak, Zarys historii parafii Modliborzyce, Janów Lubelski 1964, mps. pracy dyplomowej, s. 21. [archiwum]

${ }^{55}$ Por. T. Kliman, Annales ex libro cuiusdam Lutherani manuscripto et in Collegio Schwidnicensi asservato, 1683 , bp. 
nej formie $L u t h e^{56}$. Trwałości tej zmiany sprzyjać mogła późniejsza postępująca dezorganizacji parafii Słupie, aż do powołania parafii w Modliborzycach.

Niedługo później mogła nastąpić czasowa poprawa stanu parafii słupskiej. W 1604 r. ks. Dąbrowski, będący już w podeszłym wieku (Vitae probatae), określony został przez wizytatora jako „godny pochwały” (laudabilis). Wizytator wprost odniósł się do wydarzeń 1598 r., twierdząc, iż Dąbrowski zadośćuczynił ówczesnemu złemu stanowi kościoła odnawiając go (reformationi satisfaciat relictae a Visitatore pro Ecclesia sua $)^{57}$. Słupie nie znalazły się także pośród kilkudziesięciu parafii diecezji krakowskiej „opuszczonych” przez proboszczów, bądź opanowanych przez protestantów, które wymieniono w Księdze beneficjów retaksowanych z 1608 r. ${ }^{58}$ Wizytacja z 1604 r. nie wspomina także, aby po 1598 r. obsadzono parafię ponownie, co niejednokrotnie czyniono w podobnych sytuacjach. Ks. Dąbrowski musiał więc szybko powrócić do niej (z własnej woli czy do tego zmuszony?) i podjął działania naprawcze. Skądinąd wiemy, iż Stojeńscy z Woli z czasem porzucili protestantyzm, także jeden z wnuków Jana Stojeńskiego Mikołaj Stojeński miał być nawet prowincjałem karmelitów trzewiczkowych, „po ambonach kaznodziejskich mąż zasłużony” (ks. Kasper Niesiecki) ${ }^{59}$. Tym niemniej w latach 1592-1617 uposażenie plebana słupskiego zmniejszyło się z 4 do zaledwie 1 łanu ${ }^{60}$. Proboszcz Dobrowody, ks. Jan Karol Nerwicz, wizytator biskupi w 1637 r., podczas objazdu diecezji będąc w Urzędowie nie zastał w tamtejszym szpitalu przykościelnym prepozyta, gdyż ten przebywał wówczas

${ }^{56}$ Nie byłby to jedyny w ziemi lubelskiej przypadek nadania osadzie nazwy ukształtowanej w wyniku miejscowych stosunków wyznaniowych. Od połowy XVII do połowy XIX w. nazwę Piasków Luterskich nosiły obecne Piaski, na co wpływ miały sukcesy propagandy reformacji w tym mieście w okresie gdy jego właścicielami byli Suchodolscy. Do wykształcenia się członu „Luterskie" doszło w Piaskach nawet pomimo tego, że obok zboru luterańskiego, działał tam przez długi czas także zbór kalwiński (por. K. Bem, Zarys dziejów zboru ewangelicko-reformowanego w Piaskach Luterskich (Wielkich) koło Lublina 1563-1649-1849, „Odrodzenie i Reformacja w Polsce”, 43 (1999) s. 86-97). Aż do końca XIX w. teren dawnego zboru kalwińskiego koło Piask nazywano też Kemblow oder Piaski Luttersky (Kębłów, ob. cz. wsi Giełczew koło Piask); Osady zaginione i o zmienionych nazwach historycznego województwa lubelskiego, opr. S. Wojciechowski, A. Sochacka, R. Szczygieł, Warszawa 1986, s. 66. Poza ziemią lubelską wymienić można jeszcze chociażby wielkopolskie Lutogniewy, gdzie w końcu XVI w. istniał zbór (M. Studniarski, Lutogniewy, w: Stownik geograficzny Królestwa Polskiego i innych krajów słowiańskich, t. 5, Warszawa 1884, s. 489).

${ }^{57}$ Ośrodek Archiwów, Bibliotek i Muzeów Kościelnych Katolickiego Uniwersytetu Lubelskiego Jana Pawła II (dalej: ABMK KUL), mikrofilmy, nr 2377, bp.

${ }^{58}$ Zob. Kumor, Dzieje diecezji krakowskiej, s. 376-377.

${ }^{59}$ K. Niesiecki, Herbarz polski, wyd. J.M. Bobrowicz, t. 8, Lipsk 1841, s. 522. Być może jakoś spokrewniony był z nim Jakub Stoiński, o którym wiemy, że od 1661 r. był członkiem bractwa różańcowego przy kościele klasztornym dominikanów pw. św. Jana Chrzciciela (Muzeum Klasztoru Ojców Dominikanów w Janowie Lubelskim, Księga Bractwa Różańcowego, b. sygn., bp.). Fakt, iż było to bractwo modlitewne z sąsiedniej parafii względem Słupiów i Modliborzyc - Białej, nie wyklucza związku J. Stoińskiego ze Stojeszynem, skoro od tego samego roku członkami bialskiego bractwa byli także właściciele Modliborzyc - Jan (syn Stanisława) i Helena Wietescy (tamże).

${ }^{60}$ Bazylak, Zarys historii parafii Modliborzyce, s. 21. 
w swojej parafii w Słupiach. Prepozyta zastępował wikary. Nerwicz, dbając o dobro przebywających w szpitalu, nakazał duchownemu złożyć rezygnację z jednej z zajmowanych funkcji z powodu kumulacji beneficjów i dopuszczania się nierezydencji w Urzędowie. Gdyby nie powrócił do tego miasta, miał utracić tamtejsze beneficjum $^{61}$. Chodziło tu prawdopodobnie o wspomnianego już ks. Stanisława Ligockiego, Ligorskiego lub Ligoteckiego, proboszcza słupskiego od $1620 \mathrm{r}^{62}$, lub wzmiankowanego w 1638 r. jako posługującego w kościele słupskim niejakiego ks. Marcina, o którym niestety nic nie wiadomo ${ }^{63}$. W 1656 r. w kościele w Białej, leżącej o kilka kilometrów od Słupiów i Modliborzyc, ochrzczono Katarzynę Klosek z Wolicy k. Modliborzyc, co wyjaśniono dezorganizacją parafii słupskiej (defuncti) podczas grasowania zarazy (pestis grassantis) ${ }^{64}$. Oznaczałoby to jednak również, iż w Modliborzycach zabraknąć mogło ustanowionego tam dwa lata wcześniej mansjonarza, który mógł zastąpić duchownych ze Słupiów. Na dalszą dezorganizację parafii słupskiej, ale także ewentualną konieczność remontu kościoła w Modliborzycach, wpływać mogły również niepokoje polityczne połowy XVII w. Tłumaczyłyby one również dlaczego kościół modliborzycki konsekrowano dopiero 7 czerwca $1668 \mathrm{r}^{65}$ Nie wiemy co prawda, aby tak on sam, jak i miasto Modliborzyce oraz wieś Słupie ucierpiały wówczas, jednak nie można tego wykluczyć skoro jeszcze przed 1654 r. zniszczeniu uległ m.in. pobliski Janów. Zenon Baranowski wiąże zniszczenie tego miasta z przejściem wojsk tatarsko-kozackich traktem z Zamościa do Sandomierza przez Janów, Zaklików i Zawichost, co z pewnością wiązałoby się z przejściem także przez Słupie i Modliborzyce ${ }^{66}$. Jeszcze w 1. połowie XIX w. na polach Borownicy, między Janowem a Modliborzycami miały znajdować się mogiły skrywające doczesne szczątki uczestników rzekomej bitwy stoczonej w tej okolicy w połowie XVII w. ${ }^{67}$ Traktem przez Modliborzyce miały się także posuwać w 1655 r. sprzymierzone ze Szwedami wojska siedmiogrodzkie Gabora Bakosza ${ }^{68}$. Ogółem aż do 1658 r. z całą pewnością, spośród pobliskich miejscowości spaleniu uległy Kraśnik, Janów i Biała, przy czym

${ }^{61}$ Por. M. Surdacki, Szpital świętego Ducha i św. Leonarda w Urzędowie w XV-XVIII wieku, „Kwartalnik Historyczny”, 112 (2004) nr 2, s. 18; por. AKMKr., AV Cap., sygn. 44, s. 56-61.

${ }^{62}$ Por. S. Tylus, Duszpasterze Modliborzyc w latach 1756-1836 (w świetle materiałów metrykalnych), „Roczniki Teologiczne”, 50 (2003) s. 199.

${ }^{63}$ APL, Akta miasta Modliborzyce (dalej: AmM), sygn. 1, k. 63. Nie wykluczone także, iż chodziło tu o jedynego znanego z nazwiska prepozyta szpitalnego urzędowskiego z tego czasu, wzmiankowanego w 1629 r. Jana Szeliskiego (M. Surdacki, Urzędów w XVII i XVIII wieku. Miasto-społeczeństwo-życie codzienne, Lublin 2007, s. 402).

${ }^{64}$ Archiwum Parafialne w Janowie Lubelskim (dalej: APJ), Liber baptisatorum 1655-1694, b. sygn., bp. Skądinąd wiemy, że w 1718 r. w kościele w Modliborzycach miały znajdować się murowane grobowce z kośćmi zmarłych na zarazę, co może jednak nieco dziwić, zważywszy, że zmarłych takich zazwyczaj grzebano poza osiedlami ludzkimi.

${ }^{65}$ AKMKr., Liber ordinatorum consecrationis ecclesiarum 1646-1672, sygn. 4, t. II, k. 505v.

${ }^{66}$ Por. Z. Baranowski, Ziemia janowska w okresie wojen z połowy XVII wieku, „Korzenie Janowskie", 11 (2008) s. 6.

${ }^{67}$ Tamże, s. 7.

${ }^{68}$ Tamże, s. 9. 
najeźdźcy $\mathrm{w}$ różnym stopniu zniszczyli również tamtejsze obiekty sakralne ${ }^{69}$. Autorzy Osad zaginionych województwa lubelskiego uważają, że na północny-zachód od Polichny, w parafii słupskiej, zlokalizowana była Wola Polichnińska, wzmiankowana pierwszy raz w 1580 r., następnie w 1626 r. jako nieduża osada licząca 7 zagród, a w latach 1668-1673 już jako wieś opuszczona ${ }^{70}$. Może to wskazywać zarówno, że lokacja tej wsi nie powiodła się, jak również sugeruje ewentualne negatywne skutki wydarzeń połowy XVII w. dla miejscowego osadnictwa. Jeśli do podobnej sytuacji doszło także w Słupiach i Modliborzycach to stopień zniszczenia przynajmniej drugiego z tych kościołów nie był chyba zbyt duży, skoro nie później jak w początku 1657 r. ustanowiono go siedzibą parafii. Przypuszczać należy raczej, że domniemana nieobecność mansjonarza w Modliborzycach w 1656 r. związana była raczej ze wspomnianą epidemią grasującą wówczas w parafii słupskiej. Dodajmy, że w latach 1659-1673 znacząco zmalała liczba domostw zamieszkałych we wsiach parafii słupskiej od których oddawano podymne - ze 124 na 61, a więc dwukrotnie. Szczególnie widoczne było to w Słupiach, gdzie liczba opodatkowanych dymów zmalała z 30 do 8 (aż ponad trzykrotnie), w Wierzchowiskach z 54 do 25, zaś w Polichnie z 30 do $20^{71}$. Pociągnęło to za sobą znaczący spadek liczby parafian, skoro w 1674 r. parafię modliborzycką zamieszkiwać miało łącznie rzekomo jeszcze tylko 546 osób (bez Żydów), podczas gdy w 1682 r. parafia liczyła już aż ok. 1200 wiernych $^{72}$. Wcześniejsze wyludnienie parafii słupskiej mogło zatem dodatkowo wpłynąć na jej zniesienie i połączenie z modliborzycką, gdyż na tak słabo zaludnionym obszarze dwa okręgi parafialne traciły rację bytu. Wiarygodność ówczesnych rejestrów podatkowych bywa jednak poddawana w wątpliwość m.in. ze względu na pomijanie przez poborców niektórych podatników i dymów, a niekiedy nawet całych wsi, przygotowanie jedynie wykazów pogłównego przez miejscowe duchowieństwo - proboszczów i komendarzy, najlepiej orientujących się w zasięgu poszczególnych okręgów parafialnych ${ }^{73}$, czy błędne datowanie niektórych rejestrów poborowych ${ }^{74}$. Niemniej nawet przy założeniu, że w 1673 r. liczba domostw zwolnionych z podymnego lub po prostu nie ujętych $\mathrm{w}$ jego rejestrze $\mathrm{z}$ winy poborców lub innych czynników wzrosła w stosunku do 1659 r., a nie jest to pewne ${ }^{75}$, to i tak spadek liczby dymów opodatkowanych wydaje się znaczący. Maciej Norbert Brodacki zwrócił uwagę, że w Kraśniku liczba ludności zmniejszała się nie tylko w latach 1651-1660

${ }^{69}$ Tamże, s. 7-9; M.N. Brodacki, Kraśnik w XVIII w. Struktura i funkcjonowanie władz miasta prywatnego, Lublin 2010, mps rozprawy doktorskiej obronionej w Instytucie Historii KUL pod kierunkiem prof. dr. hab. Wiesława Müllera, s. 46.

${ }^{70}$ Por. B. Ossol., sygn. 86/II, k. 75v, 190v.

${ }^{71}$ Tamże, k. 170v, 191v.

${ }^{72}$ AKMKr., AV, sygn. 12, s. 121.

${ }^{73}$ Czyt. C. Kuklo, Demografia Rzeczypospolitej przedrozbiorowej, Warszawa 2009, s. 76-88.

${ }^{74}$ Zob. K. Chłapowski, Źródta pisane, w: Województwo sandomierskie w drugiej połowie XVI wieku, cz. 2, red. W. Pałucki, Warszawa 1993, s. 13-15.

${ }^{75}$ Poborcy najczęściej nie wymieniali pustych wsi, tymczasem w obu omawianych rejestrach znalazła się taka - Wola Polichnińska, co wskazuje na sumienność w przygotowaniu rejestrów (por. Pałucki, Przynależność własnościowa osad, w: Województwo sandomierskie, cz. 2, s. 95). 
(w wyniku działań wojennych), ale także w dalszych latach - ogółem od 1661 do 1674 r. z 808 do 604 mieszkańców, a więc o $25 \%{ }^{76}$. Być może podobna sytuacja miała miejsce w Słupiach i okolicznych miejscowościach, sięgając początkami już przed 1659 r. i wynikała np. ze zniszczeń wojennych, ukrywania się przez miejscową ludność w pobliskich lasach, epidemii lub innych niebezpieczeństw.

Ostatnim poświadczonym źródłowo proboszczem słupskim był ks. Stanisław Ligocki, w 1654 r. nazwany Plebano in Slupia et Lutowa ${ }^{77}$. Szczególnie to ostatnie określenie wydaje się interesujące, gdyż w połowie XVII w. parafia słupska obejmowała nie tylko Słupie i Lute, ale także szereg innych osad. We wsi Lute nigdy też nie zbudowano kościoła. Wyjaśnienie znaczenia tego zwrotu może leżeć w regestrach podymnego z 1659 oraz $1673 \mathrm{r}$. W pierwszym z nich liczba domostw w Lutem została „zwyczajowo” wliczona do liczby domostw w Słupiach (Solitum in Simul cum villa Stupia) ${ }^{78}$, w drugim liczba domostw w Lutem ponownie została wliczona do liczby domostw w Słupiach, oddając podymne od łącznej liczby dymów z obu wsi, czym może zaznaczono związek między nimi

(Poddani z Przedmieścia Modliborzyckiego: $:{ }^{79}$ Słupieÿ i Lutego oddali podymne $[\ldots]$ od Domów $[\ldots]$. Luthe $[\ldots]$ solutum sub Slupia $[\ldots])^{80}$.

Najwyraźniej w połowie XVII w. obie osady kojarzono z sobą, nazywając nawet przedmieściem Modliborzyc, które przed lokacją miasta mogły z sobą sąsiadować ${ }^{81}$. Sprzyjałaby temu bliskość geograficzna obu osad, oraz ich wspólni właściciele. Jeszcze w 1626 r. bracia Olbrycht, Mikołaj i Gabriel Chobrzyńscy trzymali bowiem wspólnie całe Lute oraz blisko połowę Słupi ${ }^{82}$. Dopiero domniemany rozwój Modliborzyc w kierunku północnym, który zdaniem R. Zwierzchowskiego $\mathrm{w}$ przeciwieństwie do kierunku południowego nastąpił niebawem po lokacji prawnej miasta w 1631 r., w związku z obronnymi walorami rzeki Sanny i pobliskich stawów, mógł rozdzielić wsie Słupie i Lute ${ }^{83}$. Późniejsze powstanie

${ }^{76}$ Brodacki, Kraśnik w XVIII w. Struktura i funkcjonowanie, s. 45, 47.

${ }^{77}$ APK, O.S., Hipoteka janowska, sygn. 949/189, nr 4, bp.

${ }^{78}$ B. Ossol., sygn. 86/II, k. 170v.

${ }^{79}$ Zapewne nie był to dwukropek w dzisiejszym jego znaczeniu, lecz abrewiacja o takiej postaci. Abrewiacja w postaci dwukropka równoznaczna była ze zwrotami łacińskimi typu est, que czy usque, które znaczą tyle co ,jest, równocześnie, przy tym, mianowicie, zwłaszcza, tam”. Nie chodziło więc tu o przedmieście Modliborzyc oraz Słupie i Lute, lecz Słupie i Lute, które nazwano przedmieściami Modliborzyc (por. Abrewiacje, w: Encyklopedia staropolska, t. 1, opr. Z. Gloger, Warszawa 1900, s. 3).

${ }^{80}$ B. Ossol., sygn. 86/II, k. 191v.

${ }^{81}$ Przypomnę, że przypadek podlubelskich Dłotlic, z których już w latach 1531-1533 podatek pobrano łącznie z Dysem (Stownik historyczno-geograficzny województwa lubelskiego w średniowieczu, opr. S. Kuraś, Warszawa 1983, s. 65), w 1582 r. wzmiankowano je jako Dys et Dłotlice, zaś w 1626 r. Dys i Dłotlicze parochia, autorzy Osad zaginionych tłumaczą zlewaniem się Dłotlic w jedno osiedle z sąsiednim Dysem (Osady zaginione, s. 48).

${ }^{82}$ B. Ossol., sygn. 86/II, k. 74, 75v.

${ }^{83}$ Por. R. Zwierzchowski, Modliborzyce. Korekta zasięu wpisu do rejestru zabytków uktadu urbanistycznego - nr rej. zabytków woj. lubelskiego. A/566, Lublin 2008, mps w Archiwum Wojewódzkiego Urzędu Ochrony Zabytków w Lublinie, s. 4-5. 
parafii w Modliborzycach mogła ostatecznie wpłynąć na rozbicie terytorialne parafii słupskiej i przypieczętować jej los.

\section{Powstanie parafii w Modliborzycach}

Chcąc podnieść znaczenie założonych przez siebie Modliborzyc Wieteski postanowił zapewne doprowadzić do ustanowienia tam siedziby parafii. Postąpiłby więc podobnie jak ordynat Tomasz Zamoyski, który dokonując w $1621 \mathrm{r}$. lokacji prawnej miasta Tomaszowa nakazał m.in. wzniesienie w zasięgu jego wałów nowego kościoła parafialnego. Zanim jednak to nastąpiło funkcje świątyni parafialnej dla miasta pełnił znany już od 1610 r. nieodległy kościół Św. Krzyża, poprzednio siedziba parafii w Jelitkowie ${ }^{84}$. Widać tu więc pewne podobieństwo do okoliczności fundacji kościoła w Modliborzycach. Dezorganizacja parafii słupskiej mogła tylko sprzyjać planom stolnika bełskiego. Wietescy dokładali wszelkich starań, aby jak najszybciej uzyskać od biskupa miejsca (krakowskiego) zgodę na podniesienie kościoła w Modliborzycach do rangi siedziby parafii ${ }^{85}$, jednak proces ten odbywał się, mimo jego widocznego tempa, etapami. Początkowo na miejscu kult miał sprawować jedynie mansjonariusz, pełniący zarazem funkcję wikarego, dla którego jeszcze w 1654 r. syn Stanisława Jan Michał Wieteski ufundował w Modliborzycach altarię ${ }^{86}$. Tym samym zapewniono miejscowemu kościołowi i jego wiernym duszpasterza odpowiedzialnego za sprawowanie codziennej liturgii (m.in. odprawianie mszy św., śpiewanie brewiarza) w zamian za jego utrzymanie $^{87}$. Jan Wieteski, uzyskawszy akceptację proboszcza słupskiego ks. Ligockiego, ufundował nadto jeszcze w 1654 r. szpital przykościelny w Modliborzycach ${ }^{88}$. Wieteski zapisał szpitalowi 8\% rocznej prowizji od sumy 1000 złp $^{89}$. Należy jednak podkreślić, że nie tylko wartość legatu, ale także wysokość prowizji była istotna - nieco wyższa bowiem od zwyczajowych $7 \%$ przewidzianych w praktyce wyderkafu przez konstytucję sejmową z $1635 \mathrm{r} \cdot{ }^{90}$ Był więc to legat więcej niż znaczny, charakterystyczny dla bardzo bogatych fundatorów. Wreszcie wizytacja kościoła modliborzyckiego z $1682 \mathrm{r}$. wspomina powołanie proboszcza dla tej świątyni - ks. Stanisława Tutkowskiego już 12 stycznia 1657 r. ${ }^{91}$, co potwierdza kolejna wizytacja z 1689 r. ${ }^{92}$ Już w 1657 r. procesował się z miejscową szlachtą

\footnotetext{
${ }^{84}$ Por. Szczygieł, Powstanie miasta Jelitowa (Tomaszowa), s. 103, 119.

${ }^{85}$ Por. Kumor, Dzieje diecezji krakowskiej, s. 372.

${ }^{86}$ AKMKr., AV, sygn. 66, s. 14.

${ }^{87}$ Por. P. Szkutnik, Parafia szadkowska na początku XVI w. w świetle Liber Beneficiorum Jana Easkiego, „Biuletyn Szadkowski”, 13 (2013) s. 77.

${ }^{88}$ APK, O.S., Hipoteka janowska, sygn. 949/189, nr 4, bp. Ks. J.A. Wadowski (BPAN-PAUKr., sygn. 2375, s. 329) i Zbigniew Góralski błędnie upatrywali w jego fundatorze ks. Stanisława Tutkowskiego, późniejszego proboszcza modliborzyckiego (Z. Góralski, Szpitale na Lubelszczyźnie w okresie przedrozbiorowym, cz. 2, Lublin 1999, s. 86).

${ }^{89}$ Góralski, Szpitale na Lubelszczyźnie, s. 86.

${ }^{90}$ Tenże, Szpitale na Lubelszczyźnie w okresie przedrozbiorowym, Warszawa-Łódź 1982, s. 92.

${ }^{91}$ AKMKr., AV, sygn. 12, s. 121; APK, O.S., Hipoteka janowska, sygn. 949/189, nr 4, bp.

${ }^{92}$ AKMKr., AV., sygn. 66, s. 14. Datę 1657 r. jako początek rządów ks. Tutkowskiego w Modliborzycach przywołał też Kotuła, nie podał jednak na czym oparł się (Kotuła, [maszynopis pracy], s. 18,20$)$.
} 
o należne mu dziesięciny z Wolicy ${ }^{93}$. Pierwszy (?) proboszcz modliborzycki pełnił poprzednio posługę $\mathrm{w}$ kościołach nie posiadających praw parafialnych. Był to dla niego zatem awans, a przy tym dobrze znał codzienność kościołów, które dotychczas parafialnymi nie były, takich jakim do tego momentu był prawdopodobnie kościół w Modliborzycach ${ }^{94}$.

\section{Inkorporacja terytorialna parafii słupskiej do modliborzyckiej}

Wielu badaczu, w tym Bronisław Chlebowski, Robert Przegaliński, Cyprian Walewski, ks. Marek T. Zahajkiewicz, Wit Szymanek, U. Bzdyra, ks. J. Bazylak, ks. Józef Brzozowski i G. Kotuła uznało, iż w latach po fundacji kościoła modliborzyckiego nastąpiło przeniesienie siedziby parafii ze Słupiów do Modliborzyc $^{95}$, co datowali na 1664 r., opierając się przeważnie na protokole wizytacji z 1748 r. ${ }^{96}$ Pogląd ten należy jednak zweryfikować. Co prawda w dokumencie lokacyjnym miasta z 1 maja 1642 r. Wieteski stwierdził, że po upływie przyznanej mieszczanom wolnizny, tj. w $1651 \mathrm{r}$.,

mieszczanie zgodnei $[\ldots]$ do kościoła słupskiego, podług dawnego zwyczaju dziesięcine pieniężną według ustanowienia [...] dawać i wyliczać obowiązani będą

${ }^{93}$ ABMK KUL, mikrofilmy, nr 3389, cz. I, k. 556-556v.

${ }^{94} \mathrm{~W} 1650$ r. był jednym z czterech kapelanów w kościele klasztornym brygidek p.w. Wniebowzięcia Najświętszej Maryi Panny Zwycięskiej w Lublinie (AAL, Rep. 60, sygn. A 97, k. 32v), zaś w 1656 r. był już komendarzem janowskim (Z. Baranowski, Z dziejów kultu Matki Boskiej Łaskawej w Janowie Lubelskim do 1939 roku, w: Księga cudów i łask Sanktuarium Matki Bożej Łaskawej w Janowie Lubelskim, opr. Z. Baranowski, Zamość 2014, s. 112), a więc duchownym dodanym proboszczowi bialskiemu (Janów, ob. Lubelski, należał wówczas do parafii Biała) pełniącym zapewne funkcje administratora tamtejszej drewnianej kaplicy wzniesionej w latach 1647-1648 w miejscu zjawień maryjnych, a to z powodu konieczności rezydowania miejscowego proboszcza w Białej (tamże, s. 112-113; S. Orzeł, Dominikanie w Janowie Lubelskim w latach 1660-1864, w: Janów Lubelski 1640-2000, red. B. Nazarewicz, Z. Baranowski, J. Łukaszewicz, wyd. 2, Janów Lubelski 2010, s 249; Administrator parafi, w: Encyklopedja staropolska ilustrowana, opr. Z. Gloger, Warszawa 1900, s. 10). Być może jeszcze w tym samym roku ustąpił miejsca przybyłemu do Janowa pierwszemu zakonnikowi dominikańskiemu o. Stanisławowi Chudlińskiemu, który dał początek konwentowi funkcjonującemu przy tamtejszej kaplicy i późniejszym kościele (S. Orzeł, Dominikanie w Janowie Lubelskim, s. 259), a biskup powierzył mu nowe zadanie w Modliborzycach.

${ }^{95}$ Por. BPAN-PAUKr., rkps. 2375, s. 329.

${ }^{96}$ AKMKr., AV, sygn. 45, s. 108; por. BPAN-PAUKr., sygn. 757 (C. Walewski, Opis historyczny diecezji krakowskiej z XIX w., bez daty powstania), bp; Chlebowski, Przegaliński, Modliborzyce, s. 566; M. Zahajkiewicz, Diecezja lubelska. Informator historyczny i administracyjny, Lublin 1985, s. 194; W. Szymanek, Z dziejów powiatu janowskiego i kraśnickiego, s. 280; U. Bzdyra, Historia parafii i kościoła w Modliborzycach, „Wieści Gminne”, 2 (2006) s. 18; J. Bazylak, Zarys historii parafii Modliborzyce, s. 17, przyp. 12; J. Brzozowski, Kościół parafialny w Stupiu - ciag dalszy, „Wieści Gminne”, 13 (2008) s. 30; Kotuła, [maszynopis pracy], s. 12.

${ }^{97}$ Przywilej miasta Modliborzyc, s. 5. Użytkownicy pól należących do działki przyrynkowej mieli obowiązek odprowadzania do kościoła parafialnego w Słupiach „podług dawnego zwyczaju pewną dziesięcinę pieniężną, według ustanowienia, czyli kontraktu”. (R. Szczygieł, Dokument lokacyjny miasta Tomaszowa, s. 394), natomiast od wszystkich domów w mieście i na przedmieściach 
nie oznacza to jednak, że zakładał, iż do tego czasu kościół modliborzycki nie uzyska praw parafialnych. Okręgi parafialne nie zawsze bowiem odpowiadały okręgom dziesięcinnym ${ }^{98}$, przez co mieszkańcy Modliborzyc mogliby od 1651 r. odprowadzać dziesięcinę do kościoła w Słupiach, nawet gdyby posiadali już nowy kościół parafialny w Modliborzycach. Dopiero wizytacja kościoła modliborzyckiego z 1689 r. zawiera jednoznaczne polecenie wizytatora dotyczące konieczności ,inkorporacji [...] zestarzałego” kościoła w Słupiach do kościoła modliborzyckiego (incorporandem [...] Eccl. Veteris in Slupia Dlotowa collaps ad Ecclam. Modliborzyensis ${ }^{99}$, co jednak prawdopodobnie nie oznaczało inkorporacji terytorialnej okręgu parafialnego słupskiego do modliborzyckiego, lecz całkowite przeniesienie funkcji duszpasterskich i administracyjnych ze Słupiów do Modliborzyc, o czym szerzej napiszę w dalszej części artykułu. Za to wspomniane poprzednio rejestry podymnego przynoszą informacje mogące potwierdzać hipotezę o wcześniejszej inkorporacji terytorialnej parafii słupskiej do modliborzyckiej. Otóż w rejestrze z 1659 r. występują obok siebie dwie różne parafie - Modlibozÿce Parochia, obejmująca samo tylko miasto, oraz Stupia Parochia, obejmująca Słupie, Polichnę, Wolę Polichneńską (jako „pustą”, a zatem nie zasiedloną) i Lute, oraz prawdopodobnie Wierzchowiska i Wolicę (z tych podymne pobrano dopiero iuxta iuramentum anni 1663) ${ }^{100}$. Z kolei w rejestrze z 1673 r. Słupie i wspomniane poprzednio wsie zaliczono już do parafii modliborzyckiej (spośród tych tylko z Polichny podymne pobrano iuxta iuram[entum] $A$ [nni] 1663$)^{101}$. Podobną adnotację umieszczono w rejestrze pogłównego z 1674 r. ${ }^{102}$ Najpóźniej w tym samym roku rozpoczęto też prowadzić w modliborzyckiej kancelarii parafialnej księgi chrztów i ślubów ${ }^{103}$, z których najstarsze nie zachowały się ${ }^{104}$. Tymczasem ks. Tutkowski wzmiankowany w 1662 r. jako proboszcz w Modliborzycach, w 1667 r. wystąpił już jako „proboszcz ze Słupi i Modliborzyc”"105, co może nie było przypadkowe i świadczyło o połączeniu obu parafii. Nie mógł być on w każdym razie plebanem zarówno w Słupiach, jak i Modliborzycach, nawet pomimo niewielkiej odległości między nimi, gdyż ze względu na obowiązek rezydencji w parafii, co najmniej od połowy XVI w. surowo zakazywano takiego łączenia beneficjów plebańskich, zezwalając jedynie na kumulację tzw. beneficjów pro-

po 2 grosze (tamże, s. 397). Należności te miano regulować corocznie na św. Marcina, a więc 11 listopada (tamże, s. 394).

${ }^{98}$ Por. Plisiecki, Z badań nad siecia parafialna i dziesięcinna, s. 5 i nn.

${ }^{99}$ AKMKr., AV, sygn. 66, s. 16.

${ }^{100}$ B. Ossol., sygn. 86/II, k. 170v.

${ }^{101}$ Tamże, k. 191v.

${ }^{102}$ AGAD, Archiwum Skarbu Koronnego, Dz. 1, nr 162, k. 61.

${ }^{103}$ Por. AAL, Rep. 60, sygn. A 186, s. 845.

${ }^{104}$ Zdaniem U. Bzdyry najstarsza księga metrykalna przechowywana obecnie w Archiwum Parafialnym w Modliborzycach obejmuje lata 1736-1798 (por. U. Bzdyra, Syn ziemi modliborzyckiej Wincenty Pieńkowski, „Wieści Gminne”, 14 (2009) s. 24), choć w rzeczywistości najstarszą zachowaną księgę chrztów prowadzono od 1756 r. Księgi starsze znajdowały się na parafii jeszcze w 1901 r. (por. Z. Sułowski, Dzieje zaludnienia obecnych powiatów kraśnickiego i janowskiego, w: Z dziejów powiatu kraśnickiego, red. K. Myśliński, J. Szaflik, Lublin 1963, s. 36, przyp. 8).

${ }^{105}$ APJ, Liber baptisatorum 1655-1694, b. sygn., bp. 
stych, nie wymagających rezydowania ${ }^{106}$. Stąd wniosek, że między 1659 a 1667 r. doszło prawdopodobnie do inkorporacji terytorialnej parafii słupskiej do modliborzyckiej. Poprzedzałoby to przeprowadzenie najpóźniej w styczniu $1657 \mathrm{r}$. parcelacji parafii słupskiej poprzez wydzielenie z jej terytorium dla nowej parafii niewielkiego obszaru obejmującego samo miasto Modliborzyce. Do inkorporacji doszło natomiast może w 1664 r., którą datę podaje protokół wizytacji parafii z 1748 r. Błędna byłaby jedynie informacja ówczesnego wizytatora, że odbyło się to $\mathrm{w}$ formie przeniesienia siedziby parafii, co oznaczałoby, że aż do $1664 \mathrm{r}$. istniała tylko jedna parafia - słupska, do której stale należały Modliborzyce. Błąd taki nie jest wykluczony, skoro od tego wydarzenia mijało wówczas 80. lat, a ówczesny proboszcz modliborzycki ks. Maciej Kowalski prawdopodobnie nigdy nie zetknął się z ks. Tutkowskim, zapewne najlepiej poinformowanym o przyczynach zniesienia samodzielności parafii słupskiej i zmarłym wiele lat przed $1748 \mathrm{r}$.

\section{Przenoszenie wyposażenia i funkcji rezydencjonalno-gospodarczych ze Słupiów do Modliborzyc}

W późniejszych latach w kościele w Modliborzycach znalazły się pewne elementy wyposażenia kościoła w Słupiach, co musiało mieć związek z opisanymi wyżej wydarzeniami. Były to m.in. zachowane do dziś sześć brązowych lichtarzy z herbem Gozdawa i syglami SL oraz datą 1641 r., które mogą stanowić monogram ks. Stanisława Ligockiego i świadczyć o nim jako ich fundatorze ${ }^{107}$. Do dziś w kościele w Modliborzycach znajduje się również wspomniane już nadproże $\mathrm{z}$ drewnianego portalu o wykroju w ośli grzbiet $\mathrm{z}$ datą 1643 I Iuny, który pochodzi, jak chcą niektórzy, z kościoła słupskiego ${ }^{108}$. W $1781 \mathrm{r}$. w kościele modliborzyckim pośród kilku innych znajdował się także obraz św. Marii Magdaleny, być może pochodzący z ówczesnej kaplicy słupskiej jej wezwania ${ }^{109}$. Nie wiemy jednak jak długo te i inne elementy wyposażenia kościoła słupskiego przenoszono do Modliborzyc - czy część przeniesiono od razu, czy też dopiero po całkowitym odebraniu kościołowi słupskiemu funkcji miejsca kultu? Protokoły wizytacji kościoła modliborzyckiego nie pozwalają na to pytanie udzielić jednoznacznej odpowiedzi. Wiemy za to, że najpóźniej w 1682 r. przeniesiono do Modliborzyc szkołę parafialną, która poprzednio funkcjonowała w Słupiach ${ }^{110}$. Proboszczowie modliborzyccy nadal rezydowali natomiast w Słupiach, jedynie w okresie najważ-

${ }^{106}$ R. Kuśmierczyk, Problem braku duchowieństwa parafialnego $w$ archidiakonacie włocławskim w końcu XVI w., w: Nad społeczeństwem staropolskim, red. K. Łopatecki, W. Walczak, Białystok 2007, s. 366.

107 Por. Corpus inscriptionum Poloniae, t. 6, wyd. J. Szymczak, Łódź-Piotrków Trybunalski 1993, nr 93, s. 118 (Kamieńsk, b. woj. piotrkowskie); Katalog Zabytków Sztuki w Polsce, t. 8, Województwo Lubelskie, red. R. Brykowski, E. Rowińska, Z. Winiarz-Tryzybowicz, z. 10, Powiat lubelski, Warszawa 1967, s. 44 (Zembrzyce, woj. lubelskie).

${ }^{108}$ Chlebowski, Przegaliński, Modliborzyce, s. 565; Broniewski, Modliborzyce, w: Monografia ilustrowana ..., s. 96; Katalog zabytków sztuki w Polsce, t. 8, z. 7, s. 11.

${ }^{109}$ AAL, Rep. 60, sygn. A 105, s. 59.

${ }^{110}$ Czyt. szerzej AKMKr., AV, sygn. 12, s. 120; S. Kot., Szkolnictwo parafialne w Małopolsce XVI-XVIII wieku, Lwów 1912, s. 230-231. 
niejszych świąt mieszkając przy nowym kościele parafialnym. Wizytacja z $1689 \mathrm{r}$. wzmiankuje bowiem rezydencję plebana w Słupiach, oraz znajdujący się w Modliborzycach jedynie dom wikarego ${ }^{111}$. Duszpasterstwo prowadzono zasadniczo już w Modliborzycach, ale w święta tytularne i w razie potrzeby msze odprawiano jeszcze w Słupiach ${ }^{112}$. Z treści cytowanego poprzednio dekretu reformacyjnego kościoła modliborzyckiego z 1689 r. wnioskujemy, że do ,inkorporacji” kościoła słupskiego (zapewne w sensie administracyjno-materialnym) winno zdaniem wizytatora dojść już wcześniej, lub też nie została ona w pełni przeprowadzona. Jeszcze wizytacja z 1748 r. potwierdza, że tylko wikary (względnie wikariusze) zamieszkiwał w Modliborzycach, podczas gdy miejscowy proboszcz wciąż rezydował w Słupiach. Dlatego wizytator nakazał wówczas, aby proboszcz w ciągu roku wybudował w Modliborzycach plebanię i przeniósł się tam, zaznaczając, że w przeciwnym razie ukarze go. W protokole wizytacji z tego roku mowa była o domu, który już istniał w Modliborzycach i został niepotrzebnie sprzedany przez proboszcza. Faktycznie też jeszcze w 1748 r. wzniesiono „Rezydencję drewnianą na placu plebańskim na południe" [od kościoła - D.Sz., S.T.] w Modliborzycach ${ }^{113}$. Plebanowi nakazano ponadto usunąć stare budynki gospodarcze, wznoszące się jeszcze wokół dawnego cmentarza przykościelnego w Słupiach ${ }^{114}$. Jak wiemy jednak z protokołu wizytacji z $1781 \mathrm{r}$. aż do tamtej chwili nie zostało to uczynione, a tekst tej wizytacji jednoznacznie wskazuje nawet, że niektóre z nich wciąż jeszcze były użytkowane. Według ks. Broniewskiego, po erekcji parafii modliborzyckiej, w Słupiach nadal funkcjonował folwark plebański ${ }^{115}$, co potwierdza przekaz wizytatora z 1682 r., wspominającego jakieś zabudowania plebańskie w Słupiach, w których trzymano m.in. dwie krowy ${ }^{116}$. Więcej informacji na temat tamtejszego folwarku przekazał dopiero wizytator w $1781 \mathrm{r}$. Grunty plebańskie w Słupiach stanowiły wówczas 4 łany, w tym pole, leżące jednak na piaszczystym podłożu i przez to prawie nie uprawiane, oraz sad. Teren ten zajmowały kaplica (dawny kościół parafialny), dawny dom plebana i dom czeladników, oraz liczne zabudowania gospodarcze - 2 wozownie, stajnia, duża stodoła, 5 chlewów, a wszystkie one otoczone parkanem. Pleban dysponował w nich 2 wozami, 2 końmi, kilkoma radłami, bronami, oraz licznymi krowami, drobiem i trzodą chlewną, a w stodole rocznie magazynował 10 wozów siana ${ }^{117}$. Wskazuje to zatem na wciąż dość intensywne użytkowanie zabudowań poparafialnych w Słupiach. Wiązałbym to m.in. z funkcjonowaniem szpitala przykościelnego w Modliborzycach, którego pensjonariuszom należało zapewnić wyżywienie (mięso i warzywa). To pochodziło natomiast $\mathrm{z}$ folwarku słupskiego, co w istotny

${ }^{111}$ AKMKr., AV, sygn. 66, s. 13.

${ }_{112}$ Por. tamże, s. 14; BPAN-PAUKr., sygn. 2375, s. 330.

${ }^{113}$ AAL, Rep. 60, sygn. A 105, s. 559.

${ }^{114}$ Por. D. Szulc, Zabudowania parafii św. Stanisława Biskupa w Modliborzycach w świetle wizytacji prepozyta Antoniego Franciszka Dunin-Kozickiego z 1781 r., „Archiwa, Biblioteki i Muzea Kościelne", 94 (2010) s. 327-329.

${ }^{115}$ Broniewski, Modliborzyce, s. 95.

${ }^{116}$ AKMKr., AV, sygn. 12, s. 121.

${ }^{117}$ AAL, Rep. 60, sygn. A 105, s. 567. 
sposób minimalizowało koszty utrzymania mieszkańców szpitala i uzasadniało potrzebę funkcjonowania folwarku słupskiego ${ }^{118}$. Jeszcze w $1807 \mathrm{r}$. na północ od „gościńca stojeszyńskiego” znajdował się „grunt prebendarski”"119, który w sumie dawał parafii 4,5 łanu ${ }^{120}$ uposażenia ziemskiego w Słupiach. Składało się na nie zapewne m.in. pole „Figlowski” leżące „pod wsią Słupia” (między drogą na Stojeszyn a Sanną) o powierzchni połowy łanu z łąką i ogrodem, które może nadał prebendarzowi jeszcze przed ok. 1710 r. właściciel Modliborzyc i Słupiów, Mikołaj Słoniewski ${ }^{121}$.

Zabudowania gospodarcze w Słupi straciłyby rację bytu dopiero po latach 1864-1865, gdy w ramach represji popowstaniowych car Mikołaj II wydał dwa ukazy nakazujące konfiskatę dóbr ziemskich parafii rzymskokatolickich w Królestwie Polskim, co w przypadku Modliborzyc zostało zrealizowane w $1866 \mathrm{r}$. Uniemożliwiłoby to rolnicze wykorzystanie gruntów plebańskiego i prebendarskiego w Słupiach. Tamtejsze dobra poduchowne wylicytował w 1872 r. Rosjanin Mikołaj Popow. Pozostały one w posiadaniu jego rodziny aż do 1906 r. ${ }^{122}$ Same zabudowania gospodarcze i dawny kościół słupski aż do ich rozbiórki mogły jednak pozostać w dyspozycji parafii modliborzyckiej, gdyż carskie ukazy nie wywłaszczały Kościoła z nieruchomości. Za to protokół wizytacji z $1781 \mathrm{r}$. świadczy o „degradacji” dawnego kościoła słupskiego jedynie do rangi kaplicy noszącej wówczas wezwanie św. Marii Magdaleny. Była ona jednak w dobrym stanie, pokryta dachówką i białą blachą oraz otoczona drewnianym parkanem, a skoro wciąż jeszcze posiadała jakiś, zapewne niewielki dzwon (dzwonek), kaplica ta musiała jeszcze służyć celom liturgicznym, oraz być restaurowaną ${ }^{123}$. Protokół kolejnej wizytacji generalnej z 1801 r. nie wspomina już jednak o kaplicy słupskiej ${ }^{124}$, choć wiemy, że jej budynek wciąż istniał.

\section{Ostateczna likwidacja zabudowań poparafialnych w Slupiach}

Między 1844 a 1873 r. C. Walewski zapisał w swoich notatkach, że „szczątki budowy kościoła do obecnej chwili widzieć można we wsi Słupie"125, nie podał jednak czy faktycznie sam je widział, czy też czerpał informacje o nich od osób trzecich. Ostateczną rozbiórkę kościoła (kaplicy) słupskiego przeprowadzono do-

${ }^{118}$ Por. A. Karpiński, $W$ średniowiecznych $i$ wczesnonowożytnych przytułkach, „,Kwartalnik Historyczny”, 109 (2002) z. 2, s. 128.

${ }^{119}$ APL, AmM, sygn. 5, s. 49. W 1764 w Słupiach poświadczona jest „posiadłość plebana” (APM, Liber baptisatorum 1756-1796, b. sygn., s. 27).

${ }^{120} \mathrm{O}$ uposażeniu prebendarza piszemy szerzej przy omówieniu dziejów prebendy różańcowej.

${ }^{121}$ Bazylak, Zarys historii parafii Modliborzyce, s. 21 (tu mowa o polu po Piglowskim i trzech ogrodach).

${ }^{122} \mathrm{~K}$. Latawiec, Losy majątku ziemskiego parafii rzymskokatolickiej $w$ Modliborzycach $w$ latach 1865-1915, mps przekazany przez Autora. W 1905 r. posiadłościami parafii miały być już Kol. Zamek oraz Kornelówka (Spis parafii i miejscowości XIX-wiecznej metropolii warszawskiej, t. 2 (Diecezja lubelska), opr. W. Jędraszewski, Gniezno 2011, s. 57).

${ }^{123}$ AAL, Rep. 60, sygn. A 105, s. 557-558, 565.

${ }^{124}$ Por. BPAN-PAUKr., sygn. 2375, s. 331.

${ }^{125}$ Por. BPAN-PAUKr., sygn. 757, s. 28. 
piero niedługo przed 1885 r. ${ }^{126}$ Co ciekawe kościół ten został zaznaczony jeszcze na austro-węgierskiej wojskowej mapie generalnej Europy Środkowej 1:200.000 wydrukowanej dwukrotnie w 1898 i 1910 r., przedstawiającej jednak stan topografii dla lat 1877-1879 ${ }^{127}$. Skoro więc wiemy, że kaplicę słupską ostatecznie rozebrano dopiero między 1877 a 1885 r., rodzi się pytanie czy mogło mieć to związek $\mathrm{z}$ remontem kościoła modliborzyckiego $\mathrm{z}$ lat $1883-1884^{128}$, a także ewentualnym poszukiwaniem materiału budowlanego jaki mógł zostać wykorzystany w jego trakcie ${ }^{129}$.

Słowa kluczowe: parafia, inkorporacja, Słupie, Modliborzyce, reforma trydencka

\section{BIBLIOGRAFIA}

\section{Źródła}

Archiwum Archidiecezjalne Lubelskie (AAL)

Rep. 60, sygn. A 105 (wizytacja archidiakonatu lubelskiego 1781 r.)

Rep. 60, sygn. A 186 (wizytacja archidiakonatu zawichojskiego 1801 r.)

Archiwum Główne Akt Dawnych w Warszawie (AGAD)

Archiwum Skarbu Koronnego, Dz. 1, nr 162 (rejestr pogłównego powiatu urzędowskiego 1674 r.), k. 61

Archiwum Zamoyskich, sygn. 749 (korespondencja Stanisława Wieteski)

Komisja Rządowa Spraw Wewnętrznych i Policji, sygn. 3194.

Archiwum Kurii Metropolitalnej Krakowskiej (AKMKr.)

AV, sygn. 12 (wizytacja archidiakonatu lubelskiego 1682 r.)

AV, sygn. 1 (wizytacja archidiakonatu zawichojskiego 1592 r.)

AV, sygn. 66 (wizytacja archidiakonatu zawichojskiego 1689 r.)

AV Cap., sygn. 44 (wizytacja archidiakonatu zawichojskiego 1737 r.)

AV Cap., sygn. 45 (wizytacja archidiakonatu zawichojskiego 1748 r.)

Liber ordinatorum consecrationis ecclesiarum 1646-1672, sygn. 4, t. II.

Archiwum Państwowe w Kielcach, Oddział w Sandomierzu (APK, O.S.),

Hipoteka janowska, sygn. 949/189, nr 4 (wypis z księgi grodzkiej lubelskiej z 1802 r.)

Archiwum Państwowe w Lublinie (APL)

Akta miasta Modliborzyce sygn. 1; sygn. 5.

Księgi ziemskie urzędowskie ks. 22.

${ }^{126}$ Zob. Chlebowski, Przegaliński, Modliborzyce, s. 566.

${ }^{127}$ Zob. http://lazarus.elte.hu/hun/digkonyv/topo/200e/40-51.jpg, opr. M. Jakupec, F. Kotrisch, arkusz 40-51 (dostęp: 14.08.2016).

${ }^{128}$ R. Zwierzchowski, Modliborzyce. Korekta zasięgu wpisu do rejestru zabytków, s. 4-5, przyp. 14. Przyczyną tego remontu był katastrofalny stan kościoła i sąsiednich budynków (m.in. plebanii; Kotuła, [maszynopis pracy], s. 12) wynikający z ich zaniedbania przez ks. Chryzogona Chojeńskiego, expijara, proboszcza modliborzyckiego w latach 1832-1872 (APM, Protokót z posiedzenia dozoru kościelnego z dnia 26 I - 4 II 1873, b. sygn.). W latach 1851-1872 kuria diecezjalna lubelska prowadziła nawet kilka śledztw w sprawie nadużyć jakich dopuścił się w parafii modliborzyckiej (AAL, Rep. 60, sygn. X 13, X 14, X 15).

${ }^{129}$ Chlebowski, Przegaliński, Modliborzyce, s. 566. 
Archiwum Parafialne w Janowie Lubelskim (APJ)

Liber baptisatorum 1655-1694, b. sygn.

Archiwum Parafialne w Modliborzycach (APM),

Liber baptisatorum 1756-1796, b. sygn.

Biblioteka Polskiej Akademii Nauk i Polskiej Akademii Umiejętności w Krakowie (BPAN-PAUKr.),

J.A. Wadowski, Kościoły w Lublinie i diecezji krakowskiej, t. 1, sygn. 2375.

C. Walewski, Opis historyczny diecezji krakowskiej z XIX w., sygn. 757.

Zakład Narodowy im. Ossolińskich we Wrocławiu (B. Ossol.)

sygn. 86/II (spisy podatkowe pow. urzędowskiego z XVII w.)

Adamus Jan, O prawno państwowym stosunku Litwy do Polski. Dyskusja, w: Pamiętnik VI Powszechnego Zjazdu Historyków Polskich w Wilnie 17-20 września 1935 r., cz. 2 (Protokoły), Lwów 1936, s. 86-87.

Corpus inscriptionum Poloniae, t. 6, wyd. J. Szymczak, Łódź-Piotrków Trybunalski 1993.

Dokumenty Soborów Powszechnych, t. 4 (1511-1870), opr. A. Baron, H. Pietras, Kraków 2005.

Katalog zabytków sztuki w Polsce, t. 8, red. R. Brykowski, Z. Winiarz, z. 7, przyg. I. Galicka i E. Rowińska, Warszawa 1961.

Katalog Zabytków Sztuki w Polsce, t. 8, red. R. Brykowski, E. Rowińska, Z. Winiarz-Tryzybowicz, z. 10, Warszawa 1967.

Kliman, Annales ex libro cuiusdam Lutherani manuscripto et in Collegio Schwidnicensi asservato, 1683 , bp.

Materiały źródłowe do dziejów Żydów w księgach grodzkich lubelskich z doby panowania Władysława IV i Jana Kazimierza Wazów 1632-1669, Judaica Lublinensia, opr. H. Gmiterek, t. 3, Lublin 2006.

Przywilej lokacyjny miasta Tomaszowa z 1621 roku, do druku przyg. R. Szczygieł, Tomaszów Lubelski 2012.

Przywilej miasta Modliborzyc, wyd. U. Bzdyra w: „Wieści Gminne. Wydanie specjalne 380 lat lokacji Modliborzyc", 9 (2011), s. 5.

Urzędnicy województwa bełskiego i ziemi chełmskiej XIV-XVIII wieku. Spisy, opr. H. Gmiterek, R. Szczygieł, Kórnik 1992.

Volumina legum, t. 5, wyd. J. Ohryzki, Petersburg 1860.

Zwierzchowski Roman, Modliborzyce. Korekta zasięgu wpisu do rejestru zabytków układu urbanistycznego - nr rej. zabytków woj. lubelskiego. A/566, Lublin 2008, mps.

\section{Opracowania}

Abrewiacje, w: Encyklopedia staropolska, t. I, opr. Z. Gloger, Warszawa 1900, s. 3.

Administrator parafii, w: Encyklopedja staropolska ilustrowana, opr. Z. Gloger, Warszawa 1900, s. 10.

Baranowski Zenon, Z dziejów kultu Matki Boskiej Łaskawej w Janowie Lubelskim do 1939 roku, w: Księga cudów i łask Sanktuarium Matki Bożej Łaskawej w Janowie Lubelskim, opr. Z. Baranowski, Zamość 2014, s. 112-113.

Baranowski Zenon, Ziemia janowska w okresie wojen z połowy XVII wieku, „Korzenie Janowskie", 11 (2008) s. 6-9.

Bazylik Józef, Zarys historii parafii Modliborzyce, Janów Lubelski 1964, mps.

Bazylak Józef, Zarys historii parafii Modliborzyce (cz. 1), „Korzenie Janowskie”, 6 (2006) s. 18. 
Bem Kazimierz, Zarys dziejów zboru ewangelicko-reformowanego w Piaskach Luterskich (Wielkich) koło Lublina 1563-1649-1849, „Odrodzenie i Reformacja w Polsce", 43 (1999), s. 86-97.

Brodacki Maciej Norbert, Kraśnik w XVIII w. Struktura i funkcjonowanie władz miasta prywatnego, Lublin 2010, mps.

Broniewski Kazimierz, Modliborzyce, w: Monografia ilustrowana kościołów rzymskokatolickich w Królestwie Polskim, z. 1, Warszawa 1899, s. 96

Brzozowski Józef, Kościół parafialny w Słupiu - ciąg dalszy, „Wieści Gminne”, 13 (2008) s. 30 .

Bzdyra Urszula, Dzieje Modliborzyc. Kalendarium, „Wieści Gminne”, nr 10 (2008) s. 23.

Bzdyra Urszula, Historia parafii i kościoła w Modliborzycach, „Wieści Gminne”, 2 (2006) s. 18 ,

Bzdyra Urszula, Syn ziemi modliborzyckiej Wincenty Pieńkowski, „Wieści Gminne”, 14 (2009) s. 24.

Chlebowski Bronisław, Przegaliński Robert, Modliborzyce, w: Słownik geograficzny Królestwa Polskiego i innych krajów słowiańskich, t. 6, Warszawa 1885, s. 565-566.

Chłapowski Krzysztof, Źródła pisane, w: Województwo sandomierskie w drugiej połowie XVI wieku, red. W. Pałuckiego, cz. II, Warszawa 1993, s. 13-15.

Gmiterek Henryk, Dzieje miasta w XVII-XVIII wieku, w: Dzieje Bychawy, red. R. Szczygieł, Bychawa-Lublin 1994, s. 56-57.

Góralski Zbigniew, Szpitale na Lubelszczyźnie w okresie przedrozbiorowym, Warszawa-Łódź 1982.

Góralski Zbigniew, Szpitale na Lubelszczyźnie w okresie przedrozbiorowym, cz. 2, Lublin 1999.

Jop Stanisław, Zasiedlenie Pojezierza w rejonie Ostrowa Lubelskiego (XIII-XVIII w.), Lublin 1998.

Karpiński Andrzej, W średniowiecznych i wczesnonowożytnych przytułkach, „Kwartalnik Historyczny", 109 (2002) z. 2, s. 128.

Kot Stanisław, Szkolnictwo parafialne w Małopolsce XVI-XVIII wieku, Lwów 1912.

Kotuła Grzegorz, [mps pracy magisterskiej poświęconej dziejom parafii modliborzyckiej], Lublin 2005, mps.

Kuklo Cezary, Demografia Rzeczypospolitej przedrozbiorowej, Warszawa 2009.

Kumor Bolesław, Dzieje diecezji krakowskiej, t. 4, Kraków 2002.

Kuśmierczyk Leon, Rozwój zaludnienia parafii Słupie-Modliborzyce, „Korzenie Janowskie", 10 (2008) s. 24.

Kuśmierczyk Robert, Problem braku duchowieństwa parafialnego w archidiakonacie włocławskim w końcu XVI w., w: Nad społeczeństwem staropolskim, red. K. Łopatecki, W. Walczak, Białystok 2007, s. 366.

Latawiec Krzysztof, Losy majątku ziemskiego parafii rzymskokatolickiej w Modliborzycach w latach 1865-1915, bdw.

Plisiecki Piotr, Z badań nad siecią parafialną i dziesięcinną. Przykład parafii w Dobrowodzie, „Teka Komisji Historycznej ”, 1 (2004) s. 5.

Litak Stanisław, Parafie w Rzeczypospolitej w XVI-XVIII wieku. Struktura, funkcje społeczno-religijne i edukacyjne, Lublin 2004.

Łosowski Janusz, Kancelarie miast szlacheckich województwa lubelskiego od XV do XVIII wieku, Lublin 1997.

Malesa Wojciech, Synody piotrkowskie a polskie zwyczaje liturgiczne zachowane po przyjęciu trydenckiej reformy liturgii, „Kultura-media-teologia”, 17 (2014) s. 97. 
Makuch Leopold, Uposażenie kanoników regularnych w Kraśniku, „Regionalista”, 2 (1994) s. 39.

Niesiecki Kacper, Herbarz polski, wyd. J.M. Bobrowicz, t. 8, Lipsk 1841.

Orzeł Stefan, Dominikanie w Janowie Lubelskim w latach 1660-1864, w: Janów Lubelski 1640-2000, red. B. Nazarewicz, Z. Baranowski, J. Łukaszewicz, wyd. 2, Janów Lubelski 2010, s. 249.

Osady zaginione i o zmienionych nazwach historycznego województwa lubelskiego, opr. S. Wojciechowski, A. Sochacka, R. Szczygiel, Warszawa 1986.

Pałucki Waldemar, Przynależność własnościowa osad, w: Województwo sandomierskie w drugiej połowie XVI wieku, red. W. Pałucki, cz. 2, Warszawa 1993, s. 95.

Rolska Irena, Od gotyku do baroku. Kościół Kanoników Regularnych w Kraśniku w okresie patronatu Tęczyńskich i Zamoyskich, w: Ars omnia vincit. Studia z dziejów sztuki i kultury artystycznej, red. A. Bender, M. Kierczuk-Macieszko, Lublin 2012, s. 344.

Rozwałka Andrzej, Sieć osadnicza w archidiakonacie lubelskim w średniowieczu. Studium archeologiczno-historyczne, Lublin 1999.

Sawicki Józef, Consilia Poloniae. Źródła i studia krytyczne, t. 7, Synody diecezji poznańskiej i ich statuty, Poznań 1952.

Słownik historyczno-geograficzny województwa lubelskiego w średniowieczu, opr. S. Kuraś, Warszawa 1983.

Spis parafii i miejscowości XIX-wiecznej metropolii warszawskiej, t. 2 (Diecezja lubelska), opr. W. Jędraszewski, Gniezno 2011.

Sobolewski Ludwik, Prawne aspekty unii polsko-litewskiej na przełomie XV i XVI wieku, Kraków 1994, mps. Archiwum Akt Nowych Biblioteki Jagiellońskiej.

Sułowski Zygmunt, Dzieje zaludnienia obecnych powiatów kraśnickiego i janowskiego, w: Z dziejów powiatu kraśnickiego, red. K. Myśliński, J. Szaflik, Lublin 1963, s. 36.

Surdacki Marian, Szpital świętego Ducha i św. Leonarda w Urzędowie w XV-XVIII wieku, „Kwartalnik Historyczny”, 112 (2004) nr 2, s. 18.

Surdacki Marian, Urzędów w XVII i XVIII wieku. Miasto-społeczeństwo-życie codzienne, Lublin 2007.

Studniarski M., Lutogniewy, w: Słownik geograficzny Królestwa Polskiego i innych krajów słowiańskich, t. 5, Warszawa 1884, s. 489.

Szafran Przemysław, Rozwój średniowiecznej sieci parafialnej w Lubelskiem, Lublin 1958. Szczygieł Ryszard, Dokument lokacyjny miasta Tomaszowa wzorem przy spisaniu dokumentu lokacyjnego Modliborzyc z 1642 r., w: Między tekstem a znakiem. Prace ofiarowane Profesor Barbarze Trelińskiej w siedemdziesiątą rocznicę urodzin, red. A. Jaworska, S. Górzyński, Warszawa 2013, s. 396.

Szczygieł Ryszard, Powstanie miasta Jelitowa (Tomaszowa) i jego dzieje w czasach rządów w Ordynacji kanclerskiej linii Zamoyskich, w: Tomaszów Lubelski. Monografia miasta, red. R. Szczygieł, Lublin-Tomaszów Lubelski 2011, s. 99-119.

Szkutnik Wit, Parafia szadkowska na początku XVI w. w świetle Liber Beneficiorum Jana Łaskiego, „Biuletyn Szadkowski”, 13 (2013) s. 77.

Szulc Dominik, Zabudowania parafii św. Stanisława Biskupa w Modliborzycach w świetle wizytacji prepozyta Antoniego Franciszka Dunin-Kozickiego z 1781 r., „Archiwa, Biblioteki i Muzea Kościelne”, 94 (2010) s. 327-329.

Szymanek Wit, Z dziejów powiatu janowskiego i kraśnickiego w latach 1474-1975, Kraśnik 2003.

Teodorowicz-Czerepińska Teresa, Rejestr wartości kulturowych województwa lubelskiego, Lublin 1990. 
Tylus Stanisław, Duszpasterze Modliborzyc w latach 1756-1836 (w świetle materiałów metrykalnych), „Roczniki Teologiczne”, 50 (2003) s. 199.

Wiśniowski Eugeniusz, Parafie w średniowiecznej Polsce, Lublin 2004.

Zahajkiewicz Marek, Diecezja lubelska. Informator historyczny i administracyjny, Lublin 1985.

Zielińska Ewa, Kultura intelektualna kanoników regularnych z klasztoru w Kraśniku w latach 1469-1563, Lublin 2002.

\title{
Internet
}

Elektroniczny Słownik Łaciny Średniowiecznej, http://scriptores.pl/elexicon/dostep/singleView.html?what=incorporatio\#haslo_pelny (dostęp: 14.08.2016)

\section{THE INCORPORATION OF THE DISORGANIZED PARISH \\ IN THE REPUBLIC OF POLAND IN THE POST-TRIDENTINE PERIOD ILLUSTRATED WITH THE EXAMPLE OF THE PARISHES OF SLUPIE AND MODLIBORZYCE IN THE DIOCESE OF KRAKOW}

\begin{abstract}
Summary
A case study of the parishes of Słupie and Modliborzyce allows us to analyze in detail the process of the territorial, and administrative (functional) and material incorporation of the parish located in the Republic of Poland during the post-Tridentine period. It highlights the causes of this process, gives an insight into the process, and finally enables us to analyze the obstacles that affect the rate of incorporation. Thanks to it, we can evaluate how the separateness of the parish intended for incorporation was liquidated, and we can also describe the functioning of the parish in the specific meantime, i.e. between the moment when the territorial incorporation was done and ongoing process of the material incorporation, when the new parish was characterized by a certain dualism in functioning. The territorially uniform parish, which was under the process of incorporation, functioned then with the active use of buildings of the non-existent parish, which was formally incorporated. Therefore, the incorporation of the parish appears to us as the long lasting and multistage process. In the case of Słupie and Modliborzyce, it lasted from the mid-17th to the late 18th century, and the first signs of disorganization in the parish of Stupie can be observed at least at the end of the 16th century. The half of the 16 th century marks the erection of the parish in Modliborzyce, then, a few years later, the liquidation of the independence of the parish of Słupie and its territorial incorporation into the parish of Modliborzyce. Nevertheless, transferring residential and economic functions lasted for nearly 200 years; the last parish buildings in Słupie were demolished at the end of the 19th century.
\end{abstract}

Keywords: parish, incorporation, Słupie, Modliborzyce, Tridentine reform 